\title{
Effect Analysis of the Feed-in Tariff of Renewable Energy in China
}

\author{
Xingang Zhao, Yahui Yang a, * \\ School of Economics and Management, North China Electric Power University, Beijing, China \\ ayyh_0922@163.com
}

Keywords: Renewable energy; Feed-in tariff; Policy effect; China.

\begin{abstract}
A series of supporting policies have been issued in China. Among them, power price policy plays a crucial role for promoting the development of renewable energy. An effective renewable energy power price policy is propitious to change the status of serious pollution and unreasonable power supply structure in China. In this paper, the feed-in tariff of China is introduced firstly. Then, combined with the specific situation of renewable energy industry in China, feed-in tariff's implementation effect is analyzed. At last, relevant suggestions are proposed to provide reference for the formulation of government policy.
\end{abstract}

\section{Introduction}

After the industrial revolution, energy has become the fundamental driving force of the development of global economic and society. Today's main energy is nonrenewable fossil energy which is limited and brings a lot of serious environment problems. To realize sustainable development, renewable energy must be developed.

China is a major energy consumer, but it is also a country where the energy amount of per capita is poor. Proven oil reserves in China only account for $2.3 \%$ of the world's total oil reserves, and natural gas reserves account for $1.20 \%$ [1]. The amount of oil and natural gas resources per capita only about one-fifteenth of the world average can hardly satisfy the need of social and economic development. As the growth rate of total energy production can't keep up the growth rate of total consumption, the gap and the dependence on foreign increases year by year. Xu Xiaojie, the chief expert of "China World Energy Outlook", said "The energy demand of China will account for $24 \%$ of the world's, moreover the proportion of China's incremental energy demand in the world's will be $38.5 \%$, and the energy demand trend in China will become the largest variable" [2]. In addition, China's rapid development has the characteristics of high energy consumption and high emissions. Fossil energy has caused environmental pollution. Recently, many areas in China have met with fog and haze which exposes the flaws of development strategy and energy management of China. Irrational energy structure, especially the excessive emission of coal-fired, is a major problem. Since 2003, with the rise of investment growth and the expansion of high energy-consuming industries, the growth of energy consumption has been excessive and reached $7.41 \%$.

To realize energy security, control environment pollution and achieve program objectives effectively, China is supposed to develop renewable energy and get greater strides in energy restructuring. Renewable energy, as an emerging industry and a technology-intensive industry, must be achieved the policy support and financial subsidies from government in order to realize a good development. Feed-in tariff has been introduced to promote renewable energy development since 2009. And it has continued to the present time playing a positive role in renewable energy industry of China. However, there are also some problems in implementation process. A scientific effect analysis of this policy is significant for the improvement of power price policy.

\section{Feed-in Tariff of Renewable Energy in China}

China is implementing feed-in tariff. Onshore wind power, photovoltaic power, biomass power and other renewable energies can enjoy a higher price than coal-fired electricity price. Renewable 
energy tariff surcharge is levied nationwide which is used to subsidize the operation costs of renewable energy [3].

Concrete frame of feed-in tariff in China is demonstrated in Figure 1. Renewable energy power plants submit an application of grants to the competent department of finance or energy. Competent department reports to the Treasury, NDRC and National Energy Administration. The government requires grid companies to purchase electricity from qualified renewable energy plants at the benchmark price higher than desulfurization price. The costs of grid company increase, and ultimate consumer should pay the tariff surcharge which is apportioned in sale price. Local treasury office levies tariff surcharge from grid companies and delivers the surcharge to state treasury. Certainly, grid companies would get fees which are 2\%o of the amount levied. From 2012, renewable energy development fund has been set up. The sources of fund are government finance and renewable energy tariff surcharge. In the light of the distribution of renewable energy projects, government would use the fund to subsidy relevant grid companies. Moreover, a number of supporting policies consistent with feed-in tariff have been introduced, as indicated in Table 1.

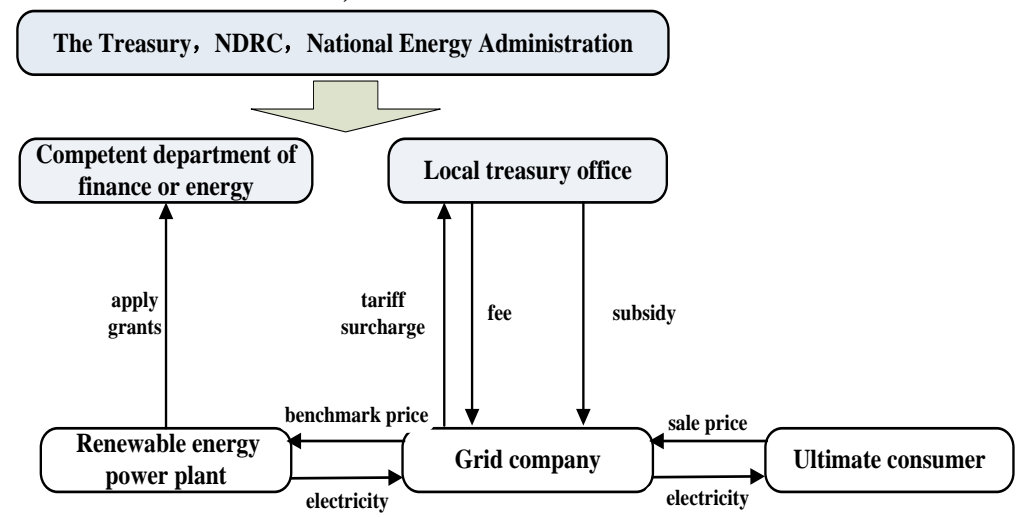

Figure 1. Frame of feed-in tariff in China.

Table 1. Supporting policies consistent with feed-in tariff.

\begin{tabular}{|c|c|}
\hline $\begin{array}{l}\text { Supporting } \\
\text { policy }\end{array}$ & Content \\
\hline $\begin{array}{l}\text { Technical } \\
\text { support }\end{array}$ & $\begin{array}{l}\text { 1.Strengthen the research of basic science and cutting-edge technology, enhance } \\
\text { the innovation ability of energy technology; } \\
\text { 2.Relying on key energy projects, promote the independent innovation of key } \\
\text { technologies and equipment, and accelerate the construction of innovative talents; } \\
\text { 3.Set up a special fund for renewable energy development, support for research } \\
\text { and development about renewable energy technology [4]. }\end{array}$ \\
\hline Tax preferences & $\begin{array}{l}\text { 1.Put the import customs of renewable energy products lower than other average } \\
\text { customs; } \\
\text { 2.Implement the tax relief, such as value-added tax [5]. }\end{array}$ \\
\hline $\begin{array}{l}\text { International } \\
\text { cooperation }\end{array}$ & $\begin{array}{l}\text { Expand the scope, channels and ways of international energy cooperation } \\
\text { vigorously, accelerate the establishment of a new international energy order, and } \\
\text { strive to achieve win-win cooperation. }\end{array}$ \\
\hline
\end{tabular}

\section{Effect Analysis}

\subsection{Effect on renewable energy industry}

Competitive power. Due to the costs of renewable energy power generation are generally higher than that of conventional energy, China has taken up the feed-in tariff to improve the competitive power of renewable energy in power sales terminal. First of all, the grid company is required to purchase all of the power from renewable energy power plants at a certain price and provide convenience for the renewable energy power to enter power grid. To some extent, the price subsidy ensures the profits of renewable energy enterprises. Secondly, carbon tax and other measures are 
implemented rising the power generation costs of the coal and gas. Thus, renewable energy power has achieved competitive power initially.

However, compared with international level, the renewable energy power price of China is still low, and the effect of subsidy has a certain international gap. The price of forestry and agricultural residues power has put into effect since 2010 and remains until now. In 2012, garbage power price was adjusted, but the overall level of change is very small.

Risk. The risk of the renewable energy industry can be divided into three kinds: price risk, production risk and balance risk.

a) Price risk: According to the price risk, feed-in tariff ensures investors a fixed return. For one thing, because of the affirmatory return as a guarantee, the investment risk of renewable energy investors and operators reduces. For another thing, this policy eliminates the costs of hedging for investors. With the expansion of renewable energy market, renewable energy subsidy increases. Since 2006, Tariff surcharge has been 1.5 Cent/kWh after the fourth adjustment (as shown in Figure 2) [6].

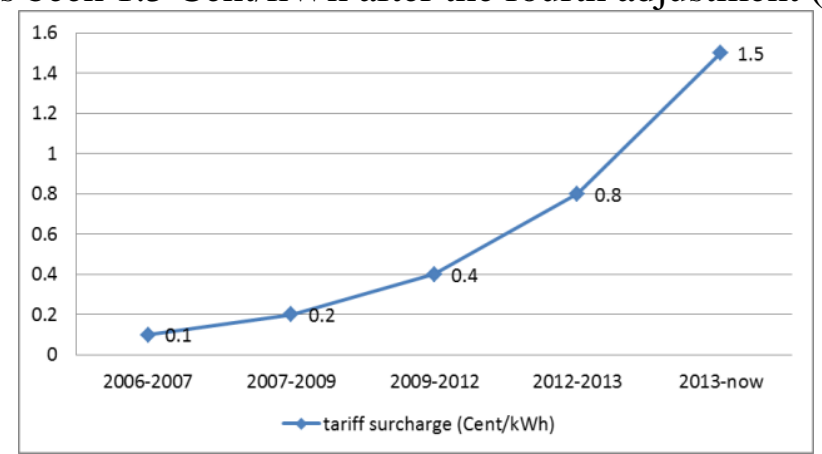

Figure 2. Adjustment of tariff surcharge in China.

b) Production risk: Grid Company is required to purchase all the power produced by renewable energy power plants mandatorily. Thus, renewable energy producers and investors wouldn't be faced the production risk caused by information asymmetry.

c) Balance risk: Power can't be stored generally and the power supply is different in different time. And power plants need to manage the load. While, in feed-in tariff, the production and load management is charged by grid company which contributes to power system's balance and stability [7].

Generating capacity. Under feed-in tariff and other relevant renewable energy policies, renewable energy industry of China has realized a leap frog development (as shown in Figure 3). Up to 2014, renewable energy installed capacity in China has been 430 million kilowatts accounting for $32 \%$ of the total. Renewable energy generating capacity has been 120 million kilowatts which is $22 \%$ of the total generating capacity [8]. Among them, solar power installed capacity has reached 30 million kilowatts. The installed capacity of biomass energy and geothermal power has been more than 9.2 million kilowatts. The new installed capacity of hydropower is nearly 20 million kilowatts. Targets of "Twelfth Five-Year Plan" have been completed up to a year in advance.

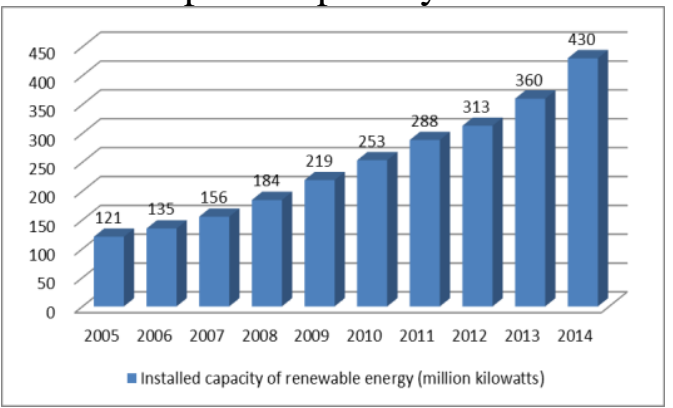

Figure 3. Installed capacity of renewable energy in China.

It is worth noting that the new installed capacity of wind power in China was 23.4 million kilowatts in 2014 and the cumulative installed capacity was nearly 115 million kilowatts. In fact, wind power in global entered a phase of slow growth in 2012 to 2013, and that in China also was into the doldrums. 
A major reason why wind power industry can realize a new rapid development in China is the support from the competent department [9].

\section{Continuity}

In April 9, 2014, the European Commission issued a new regulation and announced the subsidies for solar energy, wind energy and other renewable energy industries would be cancelled. From 2017, all EU Member States will be forced to limit the subsidy for renewable energy industry. The major reason is that feed-in tariff leads related enterprises to high costs. Along with the development of renewable energy generating capacity in China, the tariff surcharge also can't meet the demand of price subsidy and bring a huge financial burden to the government. In 2010, subsidy gap is about $30 \%$ [10]. Besides, subsidy payment is usually delayed for a long time leading to financial strain in renewable energy power plants. Therefore, the policy of feed-in tariff lacks continuity, and allocation measure of subsidy ought to be improved.

\section{Efficiency}

The essence of feed-in tariff is a subsidy policy. According to the concerned theory of economics, positive externalities can cause the market equilibrium quantity less than the optimal output. When power plants are allowanced, the power supply curve would move a little to the left, power market would deviate from equilibrium. At last, the loss of efficiency, namely EFM in Figure 4, occurs. In addition, though tariff surcharge is accounted alone, this part money would be regard as the income of grid company and needs to pay some corresponding taxes. This would lead to the shrink of the subsidy fund. Moreover, the disbursement of subsidy fund would go through many institutions and the policy's timeliness is weak. Therefore, the efficiency of feed-in tariff is low.

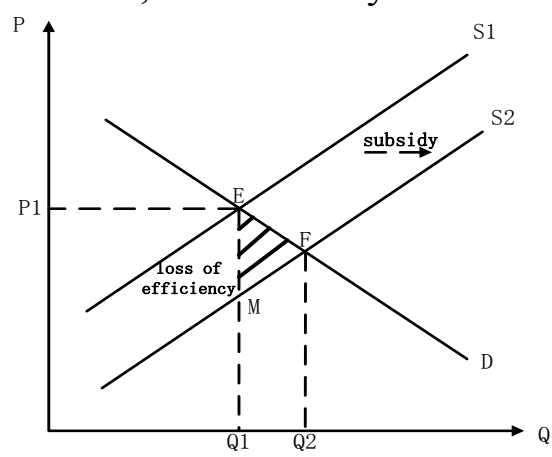

Figure 4. Loss of efficiency.

\section{Conclusion and Suggestions}

Feed-in tariff can standardize price management and set the electric price at a high level which provides a clear expectation, reduces the investment risk and contributes to solve the sales problem of renewable energy power. Meanwhile, this policy can guide the direction of renewable energy industry development in term of the wish of government. To a certain extent, feed-in tariff has pushed the industry development of renewable energy rapidly.

However, as the lack of continuity and the low efficiency, the policy of renewable energy power price is supposed to improve. Here are the following suggestions:

1) Enhance the strength of collecting tariff surcharge

In accordance with "Renewable Energy Law" of China, the strength of collecting tariff surcharge should be enhanced. Compared to the countries where cost sharing mechanism of renewable energy is implemented, like Germany and Denmark, China's tariff surcharge is relatively low. In 2013, the ratio of tariff surcharge in sales price of Germany was 20\%, but the ratio in China was only 2\% [11]. Therefore, government should raise the standard of tariff surcharge and increase the total amount of subsidy as far as possible without slowing economic growth. 
2) Formulate a reasonable subsidy scale

Subsidy scale ought to be reasonable based on the need to avoid excessive subsidy. Current renewable energy subsidy way is supposed to be adjusted. The new projects of wind power, solar power and biomass power should be approved when the subsidy has been fixed, or the power can't access to the grid.

3) Widen the channel of fund-raising

The support channels for renewable energy abroad include not only tariff surcharge but also carbon tax and energy tax [12]. Tax can regulate the market reflecting the true costs of energy. A certain proportion of fossil energy tax or carbon tax can be used to subsidize renewable energy industry and form a long-term subsidy mechanism with the original renewable energy subsidy fund.

With the development of renewable energy, feed-in tariff which enhances preferential incentives and weakens the sense of competition has been unable to meet the demand of China. The aim of electricity system reform is to introduce market and improve efficiency. And incentive methods for renewable energy should be changed from policy-oriented type to market-oriented type. So, the introduction of Renewable Portfolio Standards which plays the role of the market would be a trend.

\section{Acknowledgment}

This paper is supported by Science and technology project funding by State Grid Corporation of LiaoNing electric power co., 17 LTD. Benxi power Supply Company (Grant No. FZJS1400823, FZJS1400820).

\section{REFERENCES}

[1] Tong Ying. Analysis of the problems and countermeasures of the present situation of energy security in China. Energy and Energy Saving (11) . 2013:15-17.

[2] Liu Ningjie. The energy demand of China will affect the world. China Petroleum Daily. 2014.

[3] Fu Lushan. Study on Complementary Pattern of Renewable Portfolio Standard (RPS) and Feed-in Law(FIL) in China. Zhe Jiang University of Technology. 2008.

[4] The State Council. Energy Policy of China (2012). <http: //www. gov.cn/ zwgk/ 2012-10 /24/ content_2250617.htm >. 2012.

[5] Zhao Zhenyu, Fan Leilei. Renewable Energy Policies Analysis and its Impact on Power Generation Structure. Renewable Energy Resources Lanzhou University of Technology 28(4) . $2010: 5-9$.

[6] Shi Jingli. Efficiency Analysis of Tariff Surcharge Renewable Energy. Wind Power (12) . 2013: 50-52.

[7] Huang Junyi. Research on Pric-regulation Policies of Chinese Renewable Energies. Dongbei University of Finance and Economics. 2011.

[8] Xiao Qiang. China's Wind Power Installed Capacity has Accounted for 1/4 of the Total. China Energy News. 2015.

[9] Lu Yu. Strong Recovery of Wind Power Industry Occured in 2014. 21st Century Business Herald. 2015.

[10]Liu Lili. Renewable Energy: Heavy Subsidies. Law and Economic (10) . 2011:44-45.

[11]Xie Xuxuan, Wang Zhongying, Gao Hu. The trend of renewable energy subsidy policy in developed countries. Renewable Energy 35(8) . 2013:15-19.

[12] Li Xuemei. American renewable energy system and the Use for Reference for China. Forward Position (11) . 2013: 76-78. 